\title{
Comparative analysis of coal and coal-shale intrinsic factors affecting spontaneous combustion
}

\author{
M. Onifade ${ }^{1} \cdot$ B. Genc ${ }^{1}$ (I)
}

Received: 5 June 2018/Revised: 25 July 2018/Accepted: 1 September 2018/Published online: 12 September 2018

(C) The Author(s) 2018

\begin{abstract}
Coal and coal-shales tend to undergo spontaneous combustion under favourable atmospheric conditions. Spontaneous combustion liability index and intrinsic properties of coals and coal-shales varies between (above and below) coal seams. The spontaneous combustion liability index (obtained from the Wits-Ehac Index) and intrinsic properties (obtained from proximate, ultimate, and petrographic analysis) of fourteen samples representative of in situ coal (bituminous) and fourteen coal-shales obtained in Witbank coalfield, South Africa were experimentally studied. Comparative analysis of the relationships between the spontaneous combustion liability index and intrinsic properties of coals and coalshales were established to evaluate their effects on self-heating potential. The intrinsic properties show linear relationship with spontaneous combustion liability and therefore, identifies the factors affecting spontaneous combustion of these materials. The influence of coal-shales intrinsic properties towards spontaneous combustion liability shows higher correlation coefficients than the coals. Both coals and coal-shales show inertinite maceral as major constituents than the vitrinite and liptinite macerals, hence the reactivity of inertinite macerals may show greater influence on spontaneous combustion liability. A definite positive or negative trends exists between the intrinsic properties and spontaneous combustion liability index. This research is part of a larger project which is considering the influence of intrinsic properties of coals and coal-shales on spontaneous combustion liability.
\end{abstract}

Keywords Coal-shales $\cdot$ Spontaneous combustion $\cdot$ Liability index $\cdot$ Statistical analysis and correlation coefficient

\section{Introduction}

Spontaneous combustion causes an increase in the temperature of a thermally segregated accumulation of coal or other combustible materials due to the chemical reactions between this material and oxygen (Davidson 1990). The low-temperature oxidation exists when the heat produced is absorbed by the surrounding environment (Kim and Sohn 2012). Spontaneous combustion of coal will eventually

B. Genc

Bekir.Genc@wits.ac.za

M. Onifade

1519496@students.wits.ac.za

1 The School of Mining Engineering, University of the Witwatersrand, P.O. WITS, Johannesburg 2050, South Africa occur if nothing is done to minimize it (Onifade and Genc 2018c; Phillips et al. 2011). The liability of coal to spontaneous combustion is a function of the coal properties, geological, environmental and mining factors, which are in turn functions of various contributory factors (Smith and Glasser 2005).

The recent challenge faced by a number of coalfields in South Africa is spontaneous combustion of coals and coalshales (Onifade et al. 2018; Onifade and Genc 2018d, e; Fig. 1), which frequently causes loss of revenue and at several intervals it has led to loss of precious resources, increase in production cost, loss of properties, and an increase in rehabilitation cost. Sedimentary rocks such as coals and coal-shales contain different volumes of organic and inorganic matter in which pore spaces are embedded in the solid together with carbon-rich matter (Alpern and de 

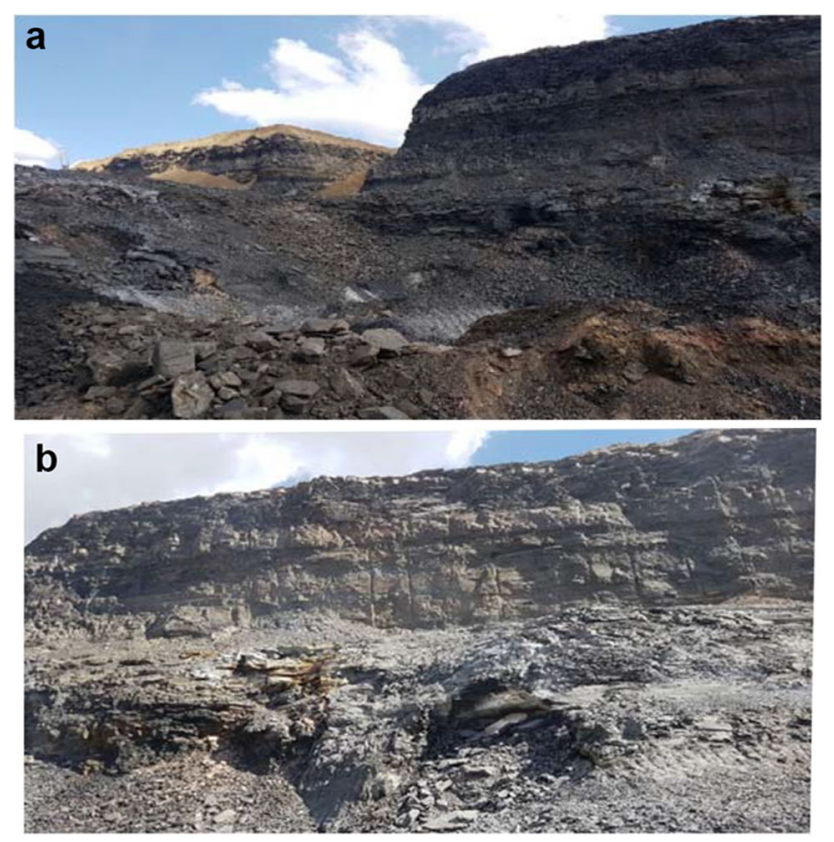

Fig. 1 a Spontaneous combustion of highwall and $\mathbf{b}$ effects of shale spontaneous combustion at at Khwezela Mine (Bokgoni Pit), Witbank, South Africa

Sousa 2002; Dullien 1979; Onifade and Genc 2018e). This renders the rock to be permeable to water and air, and with the increased surface area, the organic materials may have reactive oxidation sites (Dullien 1979). Studies reported by Mastalerz et al. (2010), Restuccia et al. (2017) and Rumball et al. (1986) indicated that for coal-shale to experience self-heating, it may contain varying proportions of sulphur (forms of sulphur), organic matter, reactive nature and rank of associated coal. Research on spontaneous combustion of coal has been examined by Beamish and Blazak (2005), Falcon (2004), Genc and Cook (2015), Gouws and Wade (1989a, b), Kaymakci and Didari (2002), Panigrahi and Sahu (2004), Panigrahi and Sexana (2001) and etc. However, a detailed investigation on the relationships between intrinsic properties of coals and coal-shales towards spontaneous combustion is limited. There is limited information to compare and contrast the intrinsic properties and spontaneous combustion liability of coal-shales in relation to coals (Onifade et al. 2018; Onifade and Genc 2018d, e). For this study, selected experimental tests on coals and coal-shales intrinsic properties (moisture, ash, volatile matter, ash, maceral compositions, total sulphur and forms of sulphur and etc.) were carried out according to the procedures of the American Society for Testing and Materials (ASTM) and International Organization for Standardization (ISO). A broad understanding of the inherent characteristic of coal-shales in relation to coal properties may be used to provide reliable information on the causes of spontaneous combustion of coals and coalshales.

\section{Materials and methods}

\subsection{Sample collection and preparation}

Samples of coal and coal-shale from four open cast mines in the Witbank Coalfield, South Africa using the ply sampling method were experimentally examined. A full description of sample and collections and preparation for both petrographic and chemical analyses tests is extensively described in the studies reported by Onifade and Genc (2018d, e).

\subsection{Wits-Ehac tests}

The Wits-Ehac Index has been developed to measure the spontaneous combustion liability of coal since the late 1980s and has been widely used in South Africa [Eroglu (1992), Genc et al. (2018), Genc and Cook (2015), Gouws and Wade (1989a, b), Onifade et al. (2018), Onifade and Genc (2018a, b, d), Uludag et al. (2001) and Wade (1989)]. Full details of the Wits-Ehac experimental procedure (Fig. 2a) are extensively explained in the studies reported by Wade et al. (1987) and Onifade and Genc (2018e). The index is calculated from the formula shown in Eq. (1) and MS Excel is used to calculate the stages and generates the thermogram (Fig. 2b).

Wits-Ehac Index $=($ Stage II slope $/$ XPT $) * 500$

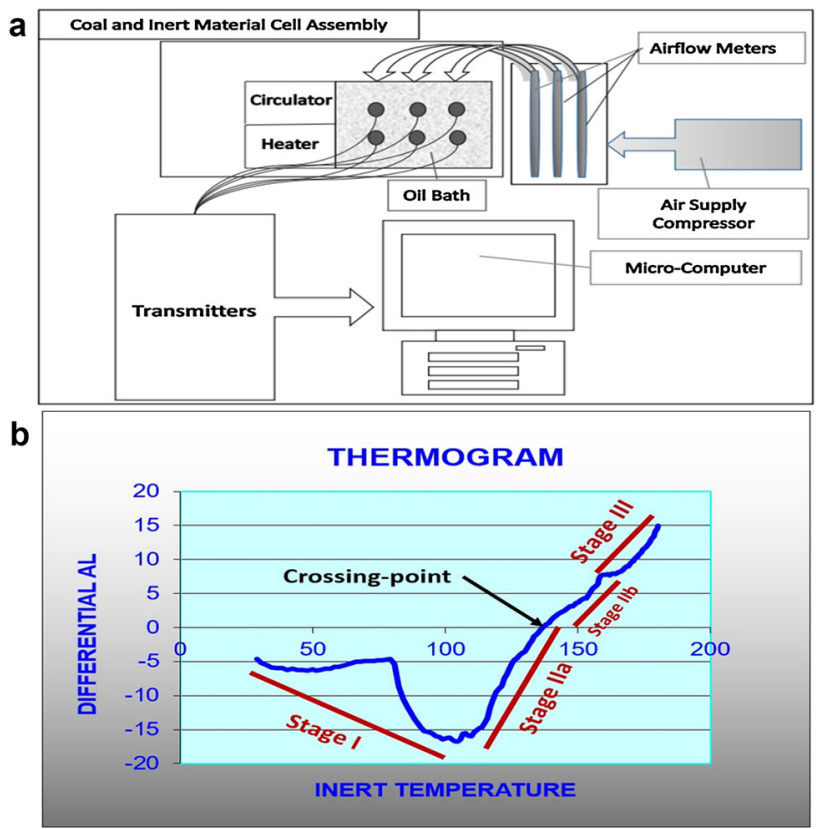

Fig. 2 a Schematic of the Wits-Ehac test apparatus setup (Wade et al. 1987). b Typical differential thermogram of a coal sample 


\section{Intrinsic properties and spontaneous combustion liability of coal and coal-shale samples}

This study used the set criterion (Table 1) documented by Onifade and Genc (2018e) to evaluate and compare the linear relationships between the intrinsic properties and spontaneous combustion liability of coals and coal-shales. Full details of the statistical analysis is reported by Onifade and Genc (2018e). The data set is divided into dependent (Wits-Ehac Index) and independent (intrinsic properties obtained from proximate, ultimate, total and forms of sulphur and petrographic analysis) variables to enable simple interpretation and analyses. The R-squared values and the correlation coefficients were used to determine the trends of relationships between the intrinsic properties and the liability index (Tables 2, 3, 4, 5, 6).

The overall database involved the Wits-Ehac Index and intrinsic properties of 14 coals and 14 coal-shales. Data were analysed using the set criterion. Tables 2, 3, 4, 5 and 6 present the results of the linear regression analyses for both the coal and coal-shale samples.

The experimental data were analysed with the use of a linear regression analysis to establish whether any of the intrinsic properties were linearly correlated to the spontaneous combustion liability index. The relationships between independent and dependent variables using the correlation coefficients and R-squared values are seen in Tables 2, 3, 4, 5 and 6. The linear regression analysis identifies linear relationships between dependent and independent variables. The analysis of variable pairs (dependent and independent) indicated consistent trends, i.e. an increase in the liability index with increasing volatile matter and vice versa for these materials. Coals and coalshales show inertinite as the major constituent among the maceral (Tables 3, 6). Weak linear relationships were noted between the Wits-Ehac Index and petrographic properties (total vitrinite, total inertinite, and total liptinite) for both coals and coal-shales (Table 7).

Table 1 Criterion for factors influencing spontaneous combustion liability of coals and coal-shales (Onifade and Genc 2018e)

\begin{tabular}{|c|c|c|}
\hline Category & Criterion & Remarks \\
\hline 1 & $\begin{array}{l}\text { Correlation coefficient/R-squared value between } 0.95 \text { and } 1 \text { or }-0.95 \\
\quad \text { to }-1\end{array}$ & $\begin{array}{l}\text { Variable indicate a perfect positive or negative linear } \\
\text { relationship }\end{array}$ \\
\hline 2 & $\begin{array}{l}\text { Correlation coefficient/R-squared value between } 0.51 \text { and } 0.94 \text { or } \\
-0.51 \text { to }-0.94\end{array}$ & $\begin{array}{l}\text { Variable indicate a strong positive or negative linear } \\
\text { relationship }\end{array}$ \\
\hline 3 & $\begin{array}{l}\text { Correlation coefficient/R-squared value between } 0.25 \text { and } 0.50 \text { or } \\
-0.25 \text { to }-0.50\end{array}$ & $\begin{array}{l}\text { Variable indicate a moderate positive or negative linear } \\
\text { relationship }\end{array}$ \\
\hline 4 & $\begin{array}{l}\text { Correlation coefficient/R-squared value between } 0.1 \text { and } 0.24 \text { or }-0.1 \\
\text { to }-2.24\end{array}$ & $\begin{array}{l}\text { Variable indicate a weak positive or negative linear } \\
\text { relationship }\end{array}$ \\
\hline 5 & Correlation coefficient/R-squared value less than 0.1 but not zero & $\begin{array}{l}\text { Variable indicate a very weak positive or negative linear } \\
\text { relationship }\end{array}$ \\
\hline 6 & Correlation coefficient/R-squared value of zero & Variable indicate no linear relationship at all \\
\hline
\end{tabular}

Table 2 Relationships between independent (proximate and ultimate analysis, wt $\%$-ad) and dependent variables for the coal samples

\begin{tabular}{lccc}
\hline Independent variables & Range & Dependent variables & \\
\cline { 3 - 4 } & & Correlation coefficients Wits-Ehac Index & R-squared values Wits-Ehac Index \\
\hline Moisture & $1.6-2.5$ & -0.0637 & 0.0041 \\
Volatile matter & $16.7-26.9$ & 0.5164 & 0.2666 \\
Ash & $13.7-48.4$ & -0.6884 & 0.4739 \\
Carbon & $36.1-69.7$ & 0.6572 & 0.4318 \\
Hydrogen & $2.55-4.21$ & 0.6616 & 0.4377 \\
Nitrogen & $0.85-1.63$ & 0.6945 & 0.4823 \\
Oxygen & $5.65-10.4$ & -0.0686 & 0.0047 \\
Sulphur & $0.59-5.30$ & -0.0115 & 0.0001 \\
Pyritic sulphur & $0.13-4.13$ & 0.0869 & 0.0076 \\
Sulphate sulphur & $0.003-0.422$ & -0.6422 & 0.4124 \\
Organic sulphur & $0.28-1.09$ & -0.1787 & 0.0319 \\
\hline
\end{tabular}


Table 3 Relationships between independent (petrographic analysis, vol\%) and dependent variables for the coal samples

\begin{tabular}{|c|c|c|c|}
\hline \multirow[t]{2}{*}{ Independent variables } & \multirow[t]{2}{*}{ Range } & \multicolumn{2}{|l|}{ Dependent variables } \\
\hline & & Correlation coefficients Wits-Ehac Index & R-squared values Wits-Ehac Index \\
\hline \multicolumn{4}{|l|}{ Vitrinite and its group } \\
\hline Total vitrinite & $7.0-49.4$ & 0.2591 & 0.0671 \\
\hline Total vitrinite (mmf) & $7.9-60.0$ & 0.0874 & 0.0076 \\
\hline Collotelinite & $1.6-39.0$ & 0.1481 & 0.0219 \\
\hline Collotelinite (mmf) & $1.7-44.4$ & 0.0439 & 0.0019 \\
\hline Collodetrinite & $2.8-13.3$ & 0.3944 & 0.1556 \\
\hline Collodetrinite (mmf) & $3.1-18.8$ & 0.1725 & 0.0298 \\
\hline \multicolumn{4}{|l|}{ Inertinite and its group } \\
\hline Total inertinite & $11.7-84.6$ & 0.1679 & 0.0282 \\
\hline Total inertinite (mmf) & $36.9-90.1$ & -0.0735 & 0.0054 \\
\hline Fusinite & $0.8-7.6$ & 0.5663 & 0.3207 \\
\hline Fusinite (mmf) & $1.2-12.1$ & 0.4392 & 0.1929 \\
\hline Secretinite & $0.8-6.0$ & 0.1284 & 0.0165 \\
\hline Secretinite (mmf) & $1.1-6.7$ & 0.0064 & 0.0001 \\
\hline Reactive semifusinite & $0.2-7.7$ & 0.1993 & 0.0397 \\
\hline Reactive semifusinite (mmf) & $0.3-8.4$ & 0.1874 & 0.0351 \\
\hline Inert semifusinite & $5.1-41.4$ & 0.2518 & 0.0634 \\
\hline Inert semifusinite (mmf) & $7.4-43.8$ & 0.0882 & 0.0078 \\
\hline Total semifusinite & $5.5-43.4$ & 0.2898 & 0.0840 \\
\hline Total semifusinite (mmf) & $14.1-45.9$ & 0.1460 & 0.0213 \\
\hline Reactive inertodetrinite & $0-4.6$ & 0.1353 & 0.0183 \\
\hline Reactive inertodetrinite (mmf) & $0-45.7$ & 0.1232 & 0.0152 \\
\hline Inert inertodetrinite & $3.2-47.1$ & -0.1111 & 0.0123 \\
\hline Inert inertodetrinite (mmf) & $10.0-50.9$ & -0.3103 & 0.0963 \\
\hline Total inertodetrinite & $3.2-49.4$ & -0.0894 & 0.0080 \\
\hline Total inertodetrinite (mmf) & $10-55.5$ & -0.2768 & 0.0766 \\
\hline \multicolumn{4}{|l|}{ Liptinite and its group } \\
\hline Total liptinite & $0.6-3.8$ & 0.0280 & 0.0008 \\
\hline Total liptinite (mmf) & $0.6-4.4$ & -0.2228 & 0.0496 \\
\hline Sporinite & $0.4-3.4$ & 0.2321 & 0.0539 \\
\hline Sporinite (mmf) & $0.7-3.8$ & 0.2116 & 0.0448 \\
\hline
\end{tabular}

$m m f$ mineral matter free basis

Table 4 Relationships between independent (total reactive maceral, total maceral and total mineral matter-vol\%) and dependent variables for the coal samples

\begin{tabular}{lccc}
\hline Independent variables & Range & \multicolumn{2}{l}{ Dependent variables } \\
\cline { 3 - 4 } & & Correlation coefficients Wits-Ehac Index & R-squared values Wits-Ehac Index \\
\hline Total reactive maceral & $11.2-53.0$ & 0.3148 & 0.0991 \\
Total reactive maceral (mmf) & $12.8-64.4$ & 0.1229 & 0.0151 \\
Total maceral & $31.7-94.6$ & 0.3785 & 0.1433 \\
Total mineral matter & $5.4-68.4$ & -0.3782 & 0.1430 \\
\hline
\end{tabular}

Total reactive is the sum of total vitrinite, total liptinite, reactive semifusinite and reactive inertodetrinite 
Table 5 Relationships between independent (proximate and ultimate analysis, wt $\%$-ad) and dependent variables for the coal-shale samples

\begin{tabular}{lccc}
\hline Independent variables & Range & Dependent variables & \\
\cline { 2 - 4 } & & Correlation coefficients Wits-Ehac Index & R-squared values Wits-Ehac Index \\
\hline Moisture & $0.8-1.7$ & 0.7715 & 0.5952 \\
Volatile matter & $8.5-16.6$ & 0.6389 & 0.4082 \\
Ash & $51.5-88.7$ & -0.8352 & 0.6975 \\
Carbon & $2.66-33.7$ & 0.7962 & 0.6339 \\
Hydrogen & $0.75-2.87$ & 0.5795 & 0.3358 \\
Nitrogen & $0.08-0.96$ & 0.6446 & 0.4155 \\
Oxygen & $5.01-11.85$ & -0.3212 & 0.1031 \\
Total sulphur & $0.12-6.90$ & 0.5791 & 0.3353 \\
Pyritic sulphur & $0.04-4.26$ & 0.5704 & 0.3254 \\
Sulphate sulphur & $0.003-0.45$ & 0.5365 & 0.2878 \\
Organic sulphur & $0.05-2.19$ & 0.5933 & 0.3519 \\
\hline
\end{tabular}

Table 6 Relationships between independent (petrographic analysis-vol\%) and dependent variables for the coal-shale samples

\begin{tabular}{|c|c|c|c|}
\hline \multirow[t]{2}{*}{ Independent variables } & \multirow[t]{2}{*}{ Range } & \multicolumn{2}{|l|}{ Dependent variables } \\
\hline & & Correlation coefficients Wits-Ehac Index & $\mathrm{R}$-squared values Wits-Ehac Index \\
\hline \multicolumn{4}{|l|}{ Vitrinite and its group } \\
\hline Total vitrinite & $0.4-8.4$ & 0.1230 & 0.0151 \\
\hline Total vitrinite $(\mathrm{mmf})$ & $2.4-39.3$ & -0.2632 & 0.0693 \\
\hline Collotelinite & $0-4.2$ & 0.2206 & 0.0487 \\
\hline Collotelinite (mmf) & $0-19.6$ & -0.1073 & 0.0115 \\
\hline Collodetrinite & $0-2.6$ & 0.2105 & 0.0443 \\
\hline Collodetrinite (mmf) & $0-12.1$ & -0.2330 & 0.0543 \\
\hline \multicolumn{4}{|l|}{ Inertinite and its group } \\
\hline Total inertinite & $4.9-46.1$ & 0.7360 & 0.5418 \\
\hline Total inertinite (mmf) & $44.9-91.7$ & 0.2143 & 0.0459 \\
\hline Fusinite & $0-4.0$ & -0.4038 & 0.2194 \\
\hline Fusinite (mmf) & $0-16.9$ & -0.5898 & 0.3479 \\
\hline Secretinite & $0-1.8$ & 0.6003 & 0.3604 \\
\hline Secretinite $(\mathrm{mmf})$ & $0-4.8$ & 0.3304 & 0.1092 \\
\hline Reactive semifusinite & $0-1.1$ & -0.2795 & 0.0781 \\
\hline Reactive semifusinite (mmf) & $0-4.6$ & -0.3862 & 0.1492 \\
\hline Inert semifusinite & $0.2-8.0$ & 0.7688 & 0.5910 \\
\hline Inert semifusinite (mmf) & $1.3-40.7$ & 0.2970 & 0.0882 \\
\hline Total semifusinite & $0.2-8.0$ & 0.7776 & 0.6046 \\
\hline Total semifusinite (mmf) & $1.3-40.7$ & 0.2970 & 0.0882 \\
\hline Reactive inertodetrinite & $0-3.6$ & 0.3292 & 0.1083 \\
\hline Reactive inertodetrinite (mmf) & $0-18.5$ & -0.0829 & 0.0069 \\
\hline Inert inertodetrinite & $1.9-34.8$ & 0.7460 & 0.5565 \\
\hline Inert inertodetrinite (mmf) & $14.8-76.6$ & 0.2480 & 0.0615 \\
\hline Total inertodetrinite & $3.3-35.2$ & 0.7749 & 0.6005 \\
\hline Total inertodetrinite (mmf) & $25.2-80.5$ & 0.2367 & 0.0560 \\
\hline \multicolumn{4}{|l|}{ Liptinite and its group } \\
\hline Total liptinite & $0.4-5.5$ & 0.3360 & 0.1129 \\
\hline Total liptinite (mmf) & $2.6-25.0$ & -0.0113 & 0.0001 \\
\hline Sporinite & $0.4-5.5$ & 0.3463 & 0.1199 \\
\hline Sporinite $(\mathrm{mmf})$ & $2.6-25.0$ & 0.0059 & 0.0001 \\
\hline
\end{tabular}


Table 7 Relationships between independent (total reactive maceral, total maceral analysis and total mineral matter-vol\%) and dependent variables for the coal-shale samples

\begin{tabular}{lccc}
\hline Independent variables & Range & Dependent variables & \\
\cline { 3 - 4 } & & Correlation coefficients Wits-Ehac Index & R-squared values Wits-Ehac Index \\
\hline Total reactive maceral & $1.6-12.8$ & 0.2923 & 0.0850 \\
Total reactive maceral (mmf) & $9.6-63.9$ & -0.2552 & 0.0651 \\
Total maceral & $9.9-53.1$ & 0.7653 & 0.5857 \\
Total mineral matter & $46.9-90.1$ & -0.7653 & 0.5857 \\
\hline
\end{tabular}

From Tables 2, 3, 4, 5 and 6, according to the criterion set, contents of volatile matter, 0.5164 ; ash, -0.6884 ; carbon, 0.6572; hydrogen, 0.6616; nitrogen, 0.6945; sulphate sulphur, 0.6422; and inertinite macerals-fusinite, 0.5663 ; with strong effects on self-heating potential are factors affecting spontaneous combustion liability of coals, while contents of moisture, 0.7715 ; volatile matter, 0.6389 ; ash, -0.8352 ; carbon, 0.7962 ; hydrogen, 0.5795 ; nitrogen, 0.6446; total sulphur, 0.5791; and its forms [pyritic, 0.5704; sulphate, 0.5365; and organic sulphur, 0.5933], total inertinite, 0.7360; and its constituents [fusinite, mmf, 0.5898; total semifusinite, 0.7776; secretinite, 0.6003; and
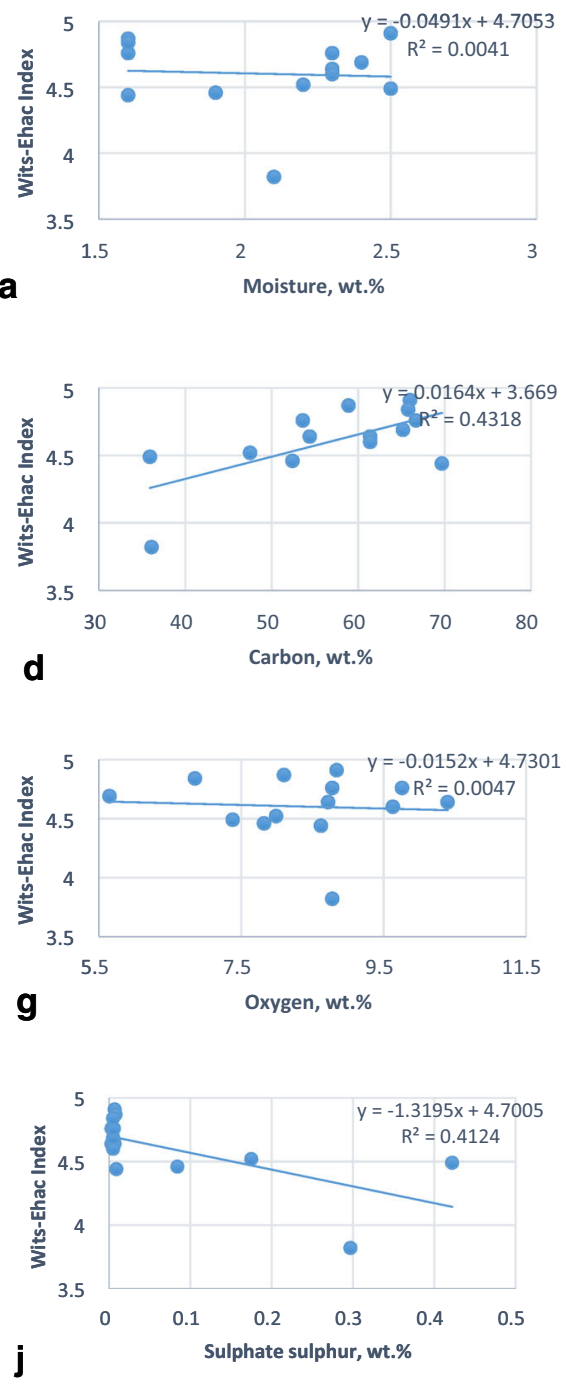
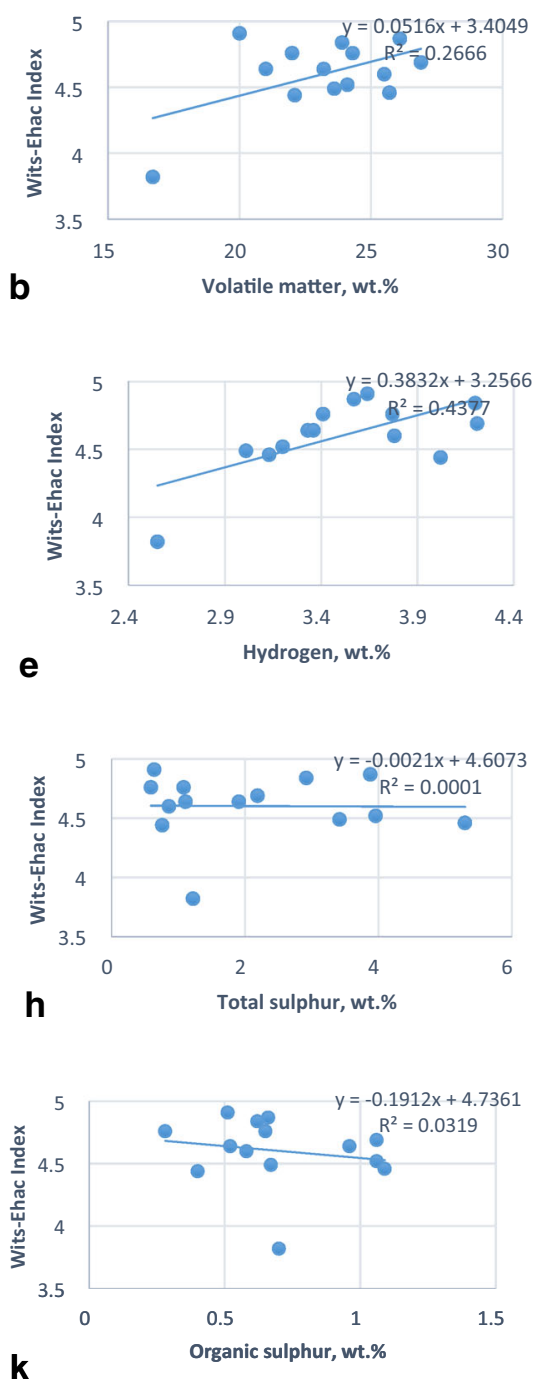
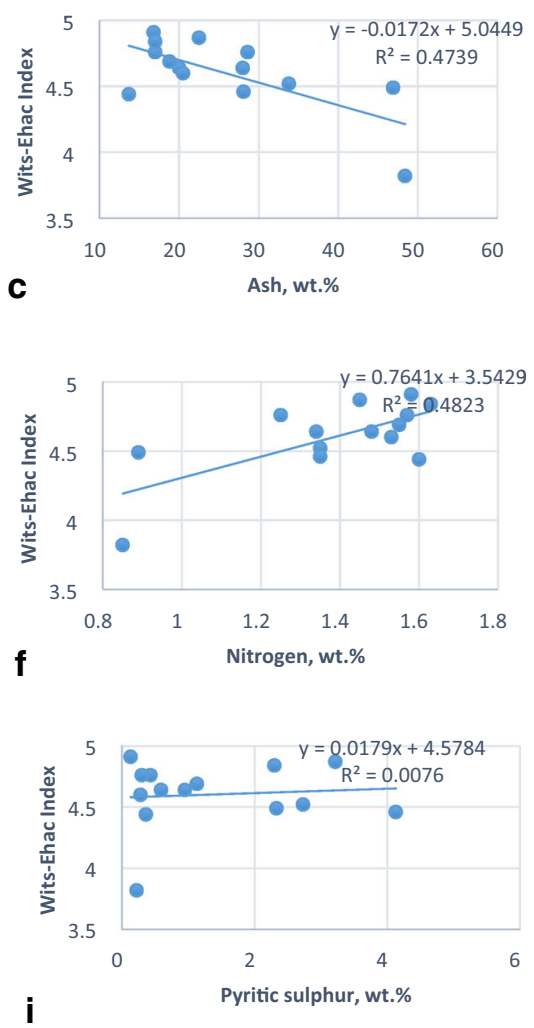

i

Fig. 3 Influence of proximate and ultimate analysis on spontaneous combustion liability of coals 

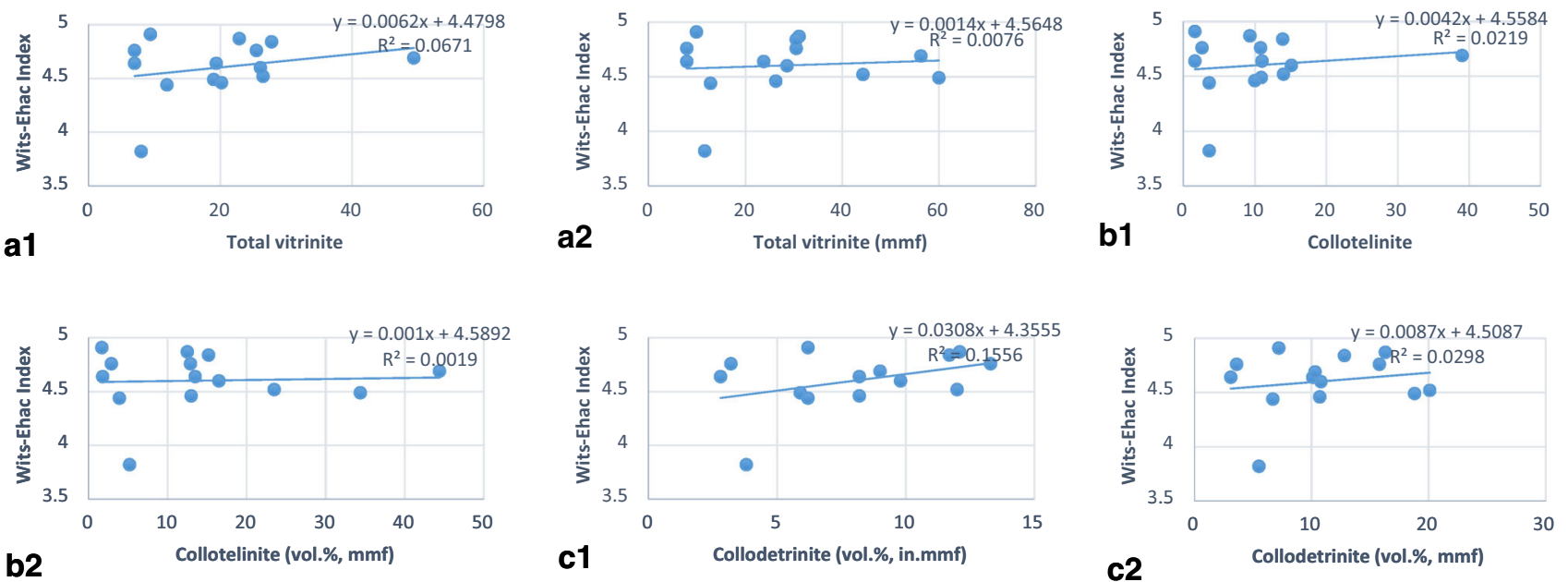

Fig. 4 Influence of vitrinite and its group on spontaneous combustion liability of coals

total inertodetrinite, 0.7749; total maceral, 0.7653; and mineral matter, - 0.7653] with strong effects on selfheating potential are factors affecting spontaneous combustion liability of coal-shales. Ash, some macerals and mineral matter contents for both coals and coal-shales show negative trends. Coal-shale intrinsic properties show better linear relationships to spontaneous combustion liability than the coals and hence, identifies the intrinsic properties influencing these materials toward spontaneous combustion. Despite the low contents of moisture, volatile matter, carbon, hydrogen, nitrogen and total sulphur in coal-shales compared to coals, the coal-shales shows significant correlation to the spontaneous liability index than the coals. The influence of intrinsic properties on spontaneous combustion liability of coals and coal-shales using statistical analysis has been extensively reported in a study by Onifade and Genc (2018e). The study created models which combined the effects of the main intrinsic properties affecting spontaneous combustion liability of these materials for predictive purposes (Onifade and Genc 2018e).
From Figs. 3, 4, 5, 6, 7, 8, 9 and 10, there is an increase in contents of moisture, volatile matter, ash, carbon, total sulphur, calculated oxygen, pyritic sulphur, organic sulphur, inertinite macerals and mineral matter in both coals and coal-shales. However, this appears to be more noticeable for coal-shales than for the coals, while coals seem to be more distinct in terms of hydrogen, nitrogen and sulphate sulphur content than coal-shales. It was found that spontaneous combustion liability of coals and coal-shales could be affected by varying proportions of one or more intrinsic properties.

\section{Conclusion}

This study has evaluated, compared and identified the relationships between intrinsic properties and spontaneous combustion liability of coals and coal-shales. The influence of selected intrinsic properties towards spontaneous combustion liability indicated a better linear relationship for the 

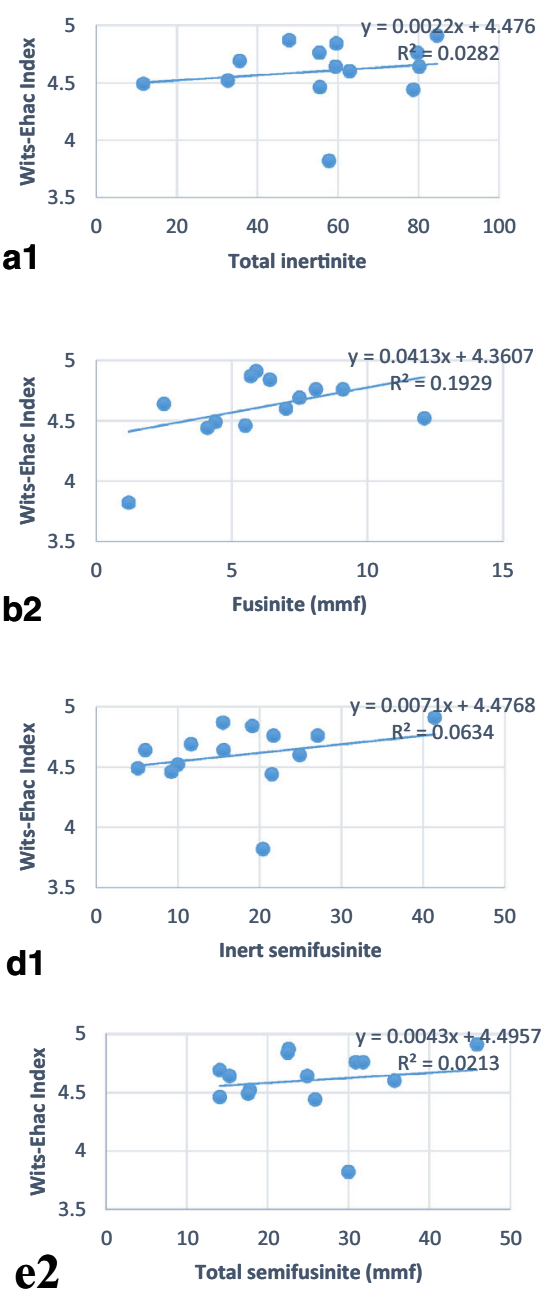

e2

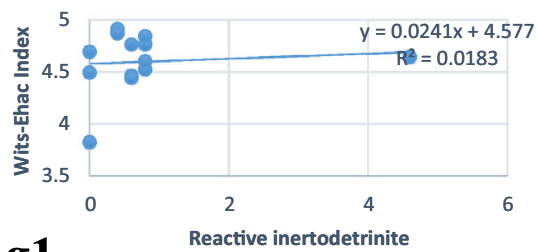

g1

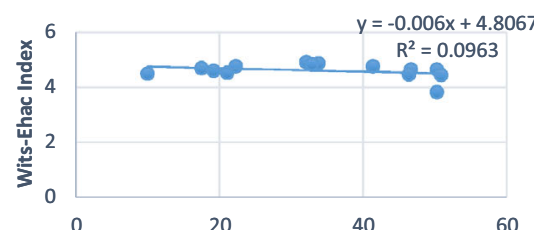

h2 Inert inertodetrinite (mmf)
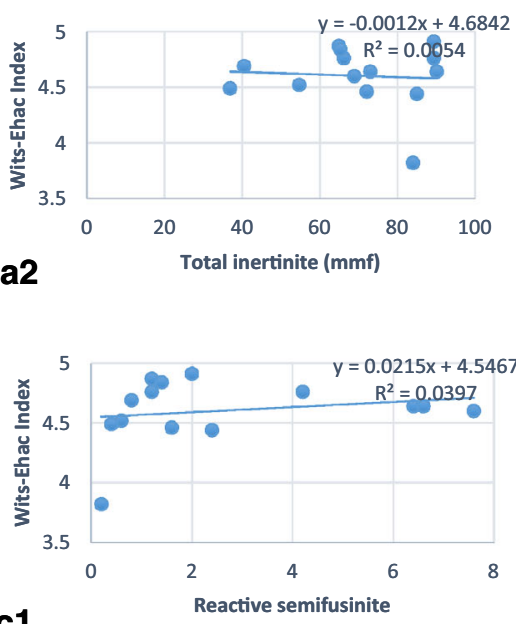

c1
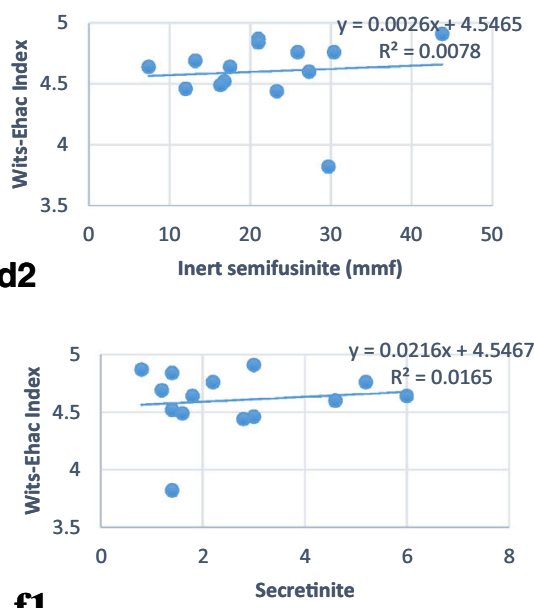

f1
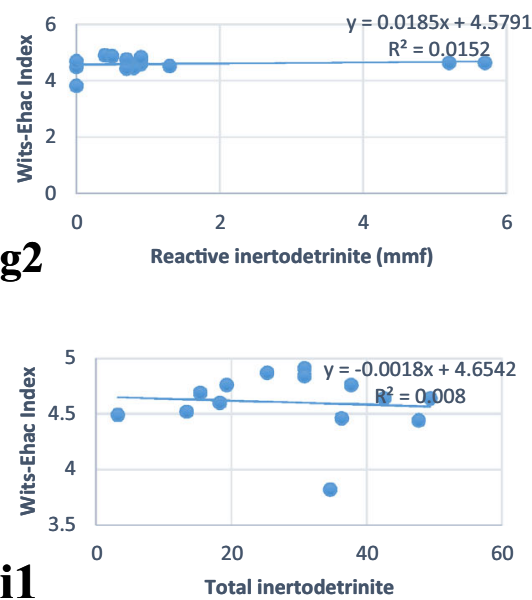

Fig. 5 Influence of total inertinite and its group on spontaneous combustion liability of coals
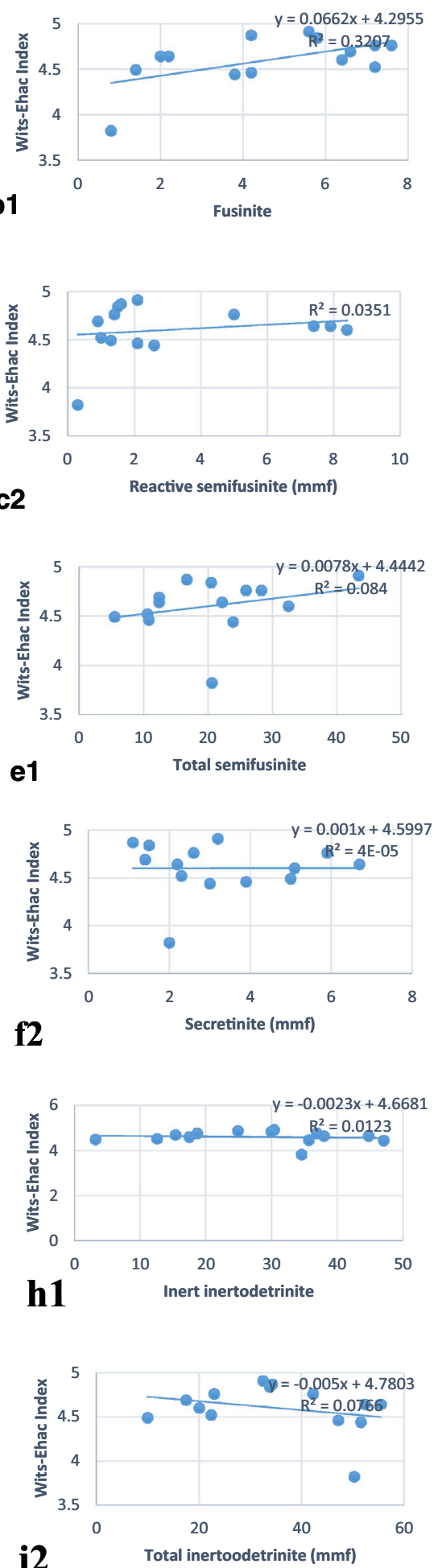

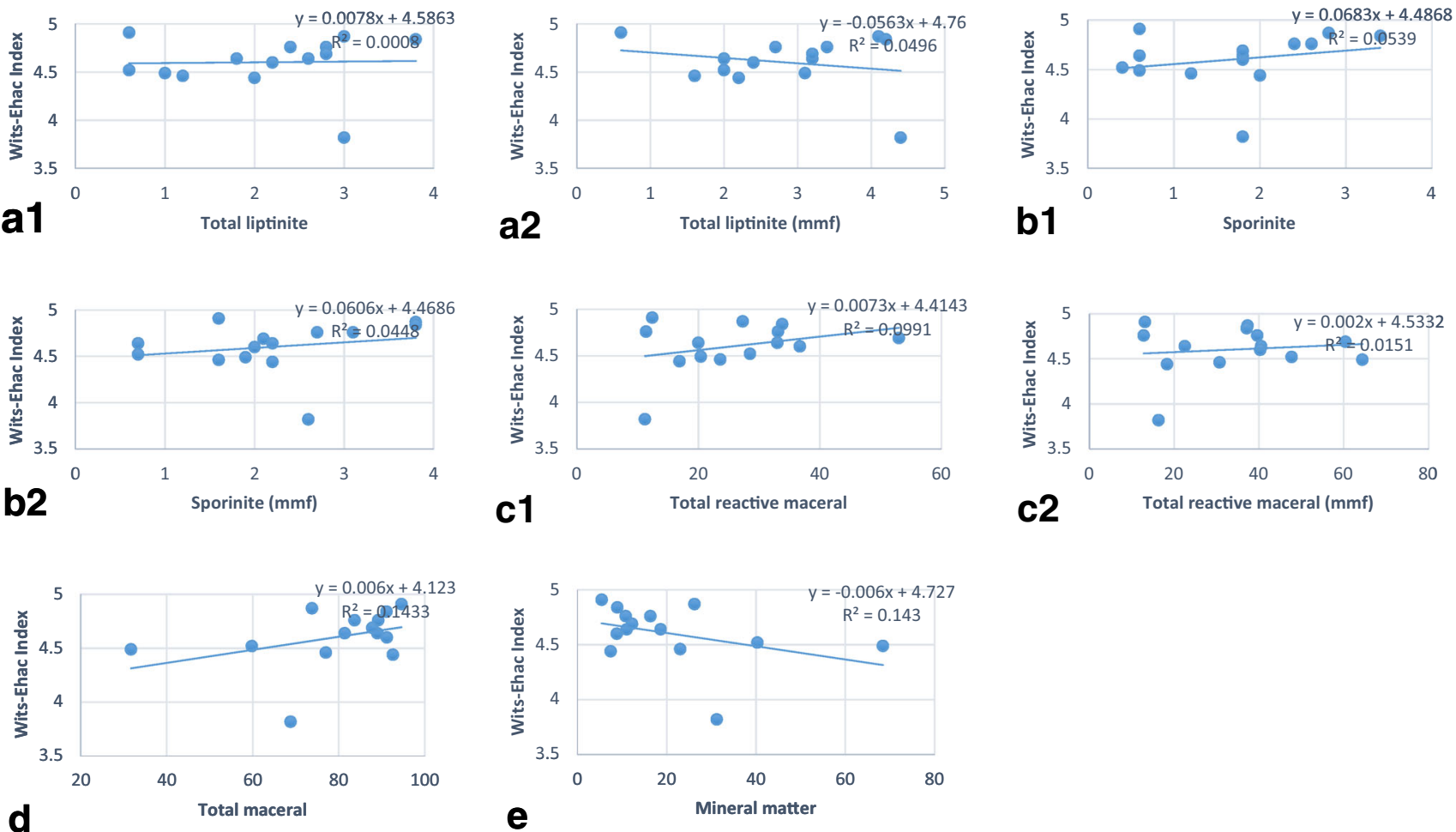

Fig. 6 Influence of total liptinite and its group, total reactive maceral, total macerals, and mineral matter on spontaneous combustion liability of coals

coal-shales than the coals, thus they may have a greater effect to cause spontaneous combustion of coal-shales. The linear regression analysis shows that among the macerals, the inertinite macerals indicated a stronger linear relationship to spontaneous combustion liability. Thus, the spontaneous combustion liability index of coals and coalshales may be influenced by the proportion of each maceral composition. A definite positive or negative correlation coefficient exists between the intrinsic factors and spontaneous combustion liability index. This paper has established a comparative analysis between the dependence of spontaneous combustion liability index on intrinsic properties of selected coal-shales and associated coals. The results obtained from the petrographic and chemical analyses may be used as a tool to predict spontaneous combustion liability and may serve as of reference when comparing characteristics of coals and coal-shales from different coalfields. 

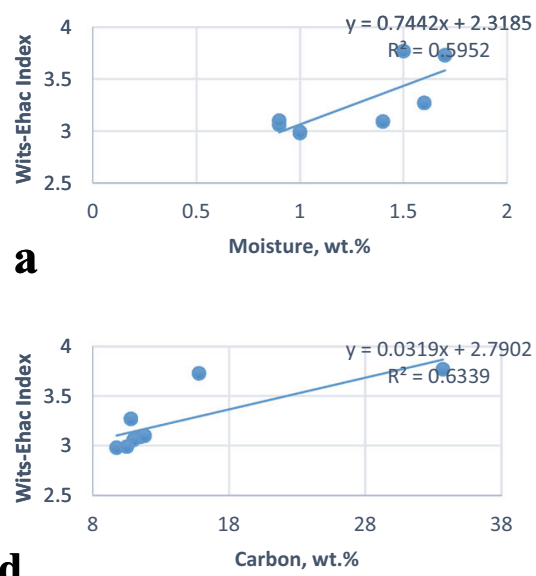

d

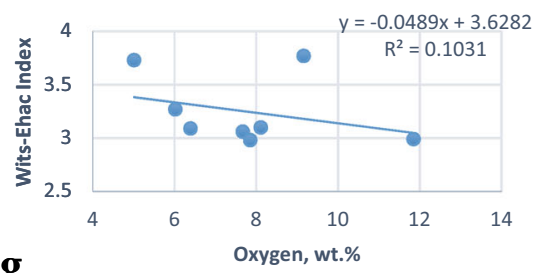

g

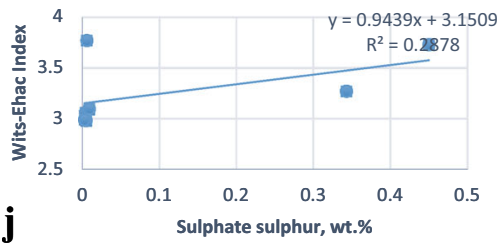

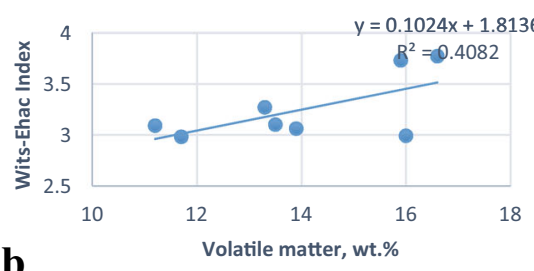

b
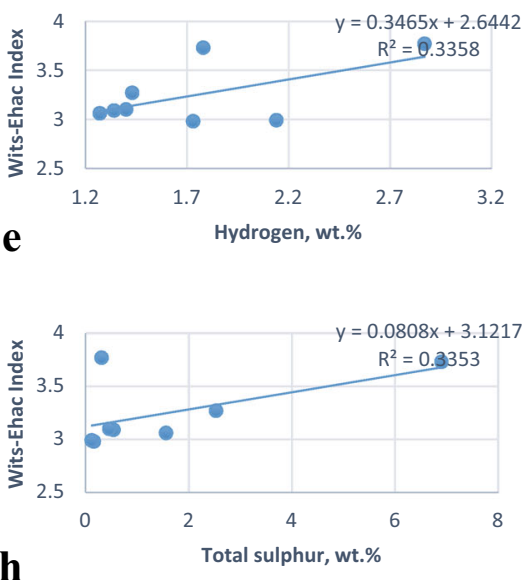

h

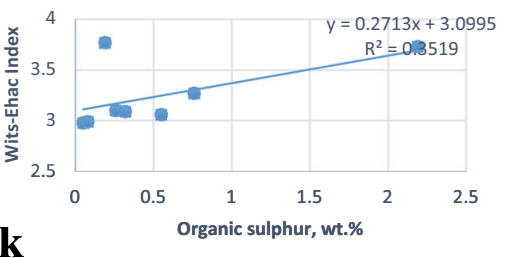

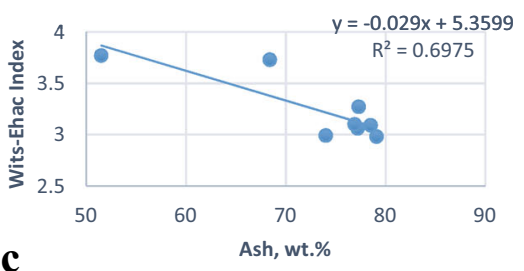
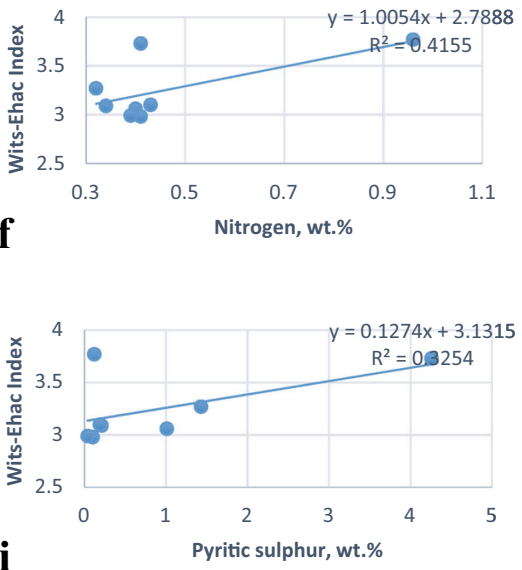

i

Fig. 7 Influence of proximate and ultimate analysis on spontaneous combustion liability of coal-shales

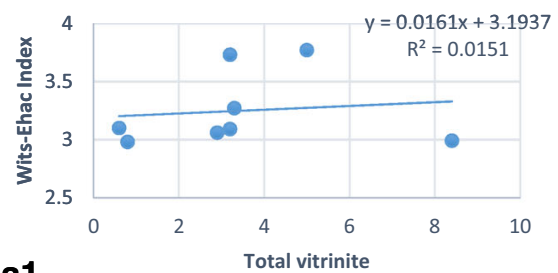

a1

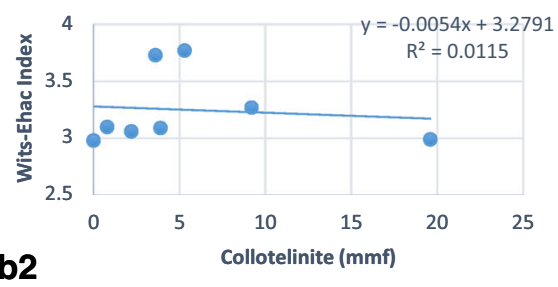

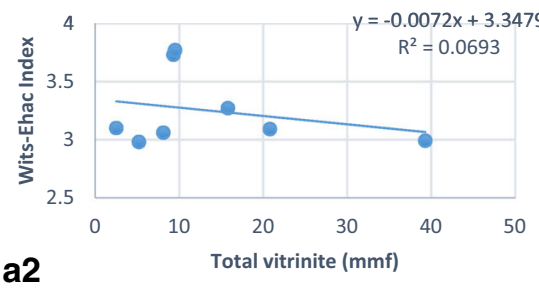

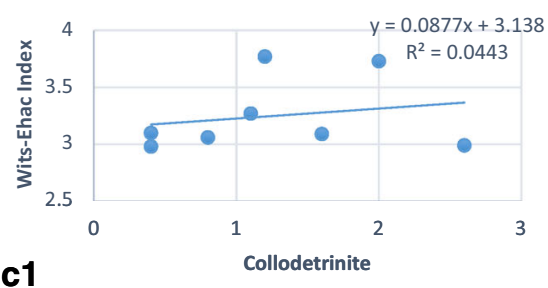

c1

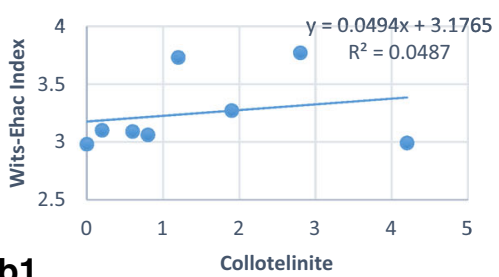

b1

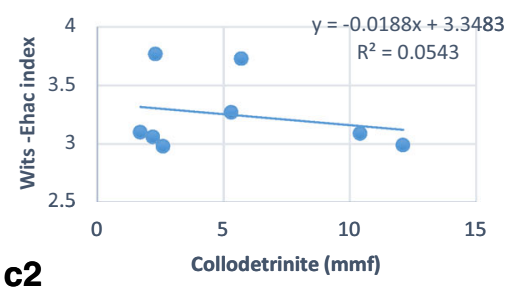

Fig. 8 Influence of total vitrinite and its group on spontaneous combustion liability of coal-shales 

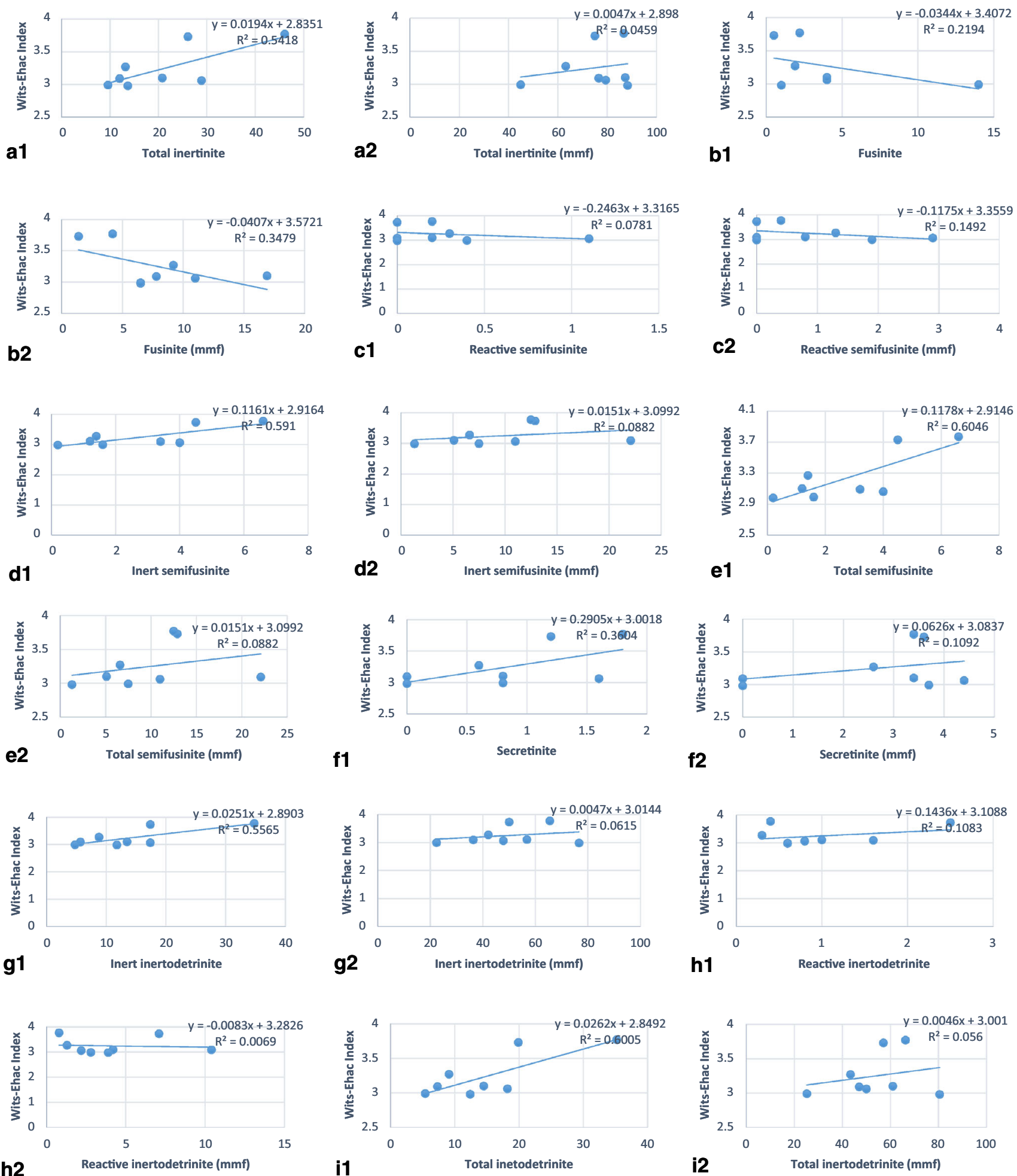

Fig. 9 Influence of total inertinite and its group on spontaneous combustion liability of coal-shales 

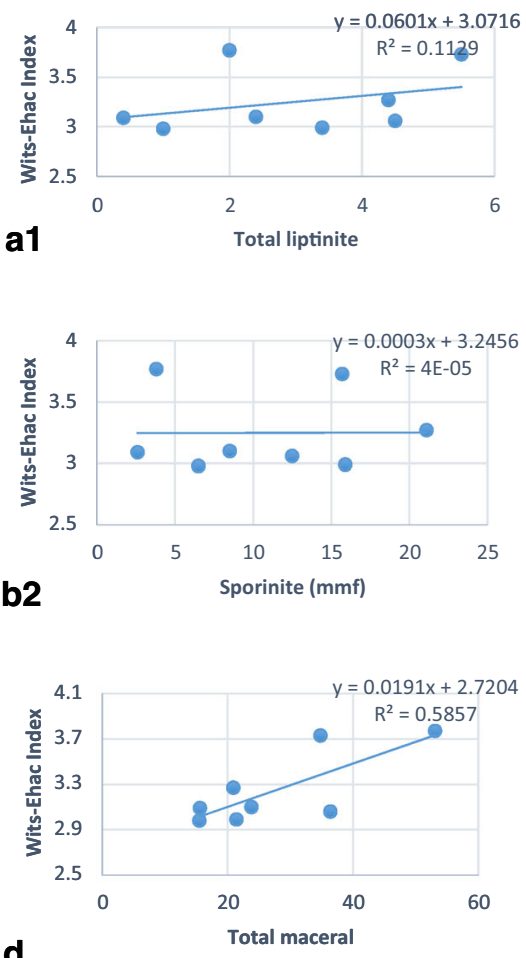

d
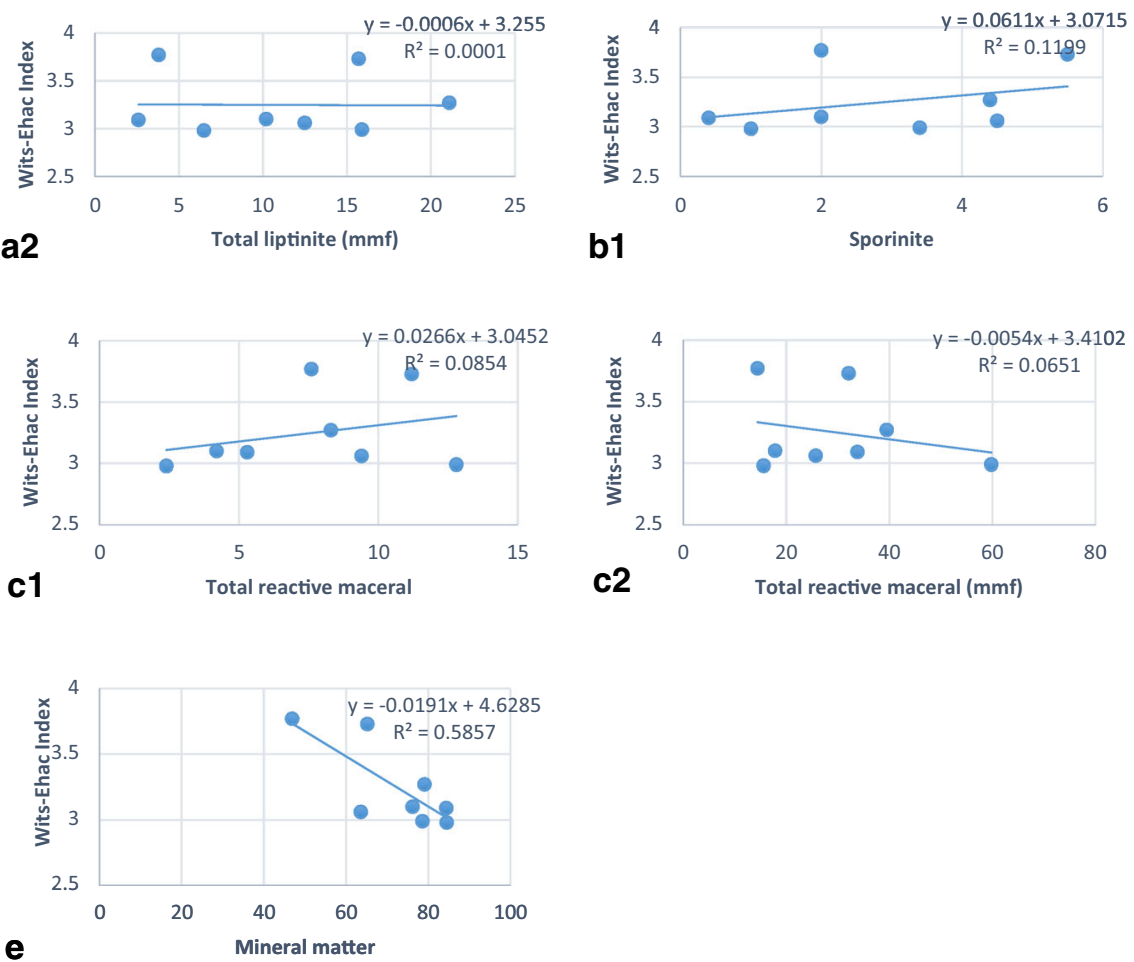

b1
Fig. 10 Influence of total liptinite, sporinite, total reactive macerals, total macerals, and mineral matter on spontaneous combustion liability of coal-shales

Acknowledgements The authors wish to express gratitude to Coaltech and Julian Baring Scholarship Fund (JBSF) for their financial support. The work presented in this paper is part of a $\mathrm{Ph} . \mathrm{D}$. research in the School of Mining Engineering at the University of the Witwatersrand.

Open Access This article is distributed under the terms of the Creative Commons Attribution 4.0 International License (http://crea tivecommons.org/licenses/by/4.0/), which permits unrestricted use, distribution, and reproduction in any medium, provided you give appropriate credit to the original author(s) and the source, provide a link to the Creative Commons license, and indicate if changes were made.

\section{References}

Alpern B, Lemo de Sousa MJ (2002) Documented international enquiry on solid sedimentary fossil fuels, coal: definitions, classification, reserves-resources, and energy potential. Int $\mathbf{J}$ Coal Geol 50:3-41

Beamish BB, Blazak DG (2005) Relationship between ash content and R70 self-heating rate of callide coal. Int $\mathrm{J}$ Coal Geol 64:126-132

Davidson RM (1990) Natural oxidation of coal. IEACR/29, London, UK, IEA Clean Coal Centre, pp 76

Dullien F (1979) Porous media fluid transport and pore structure. Academic Press, Cambridge, p 79

Eroglu HN (1992) Factors affecting spontaneous combustion liability index. Ph.D. Thesis, University of the Witwatersrand Johannesburg, South Africa, pp 157-158

Falcon RMS (2004) The constitution of coal and its inherent capacity to self-heat as applied to an integrated spontaneous combustion risk. In: Final proceedings of the international conference in spontaneous combustion. Fossil Fuel Foundation and SABS, Johannesburg, South Africa, pp 8-9

Genc B, Cook A (2015) Spontaneous combustion risk in South African coalfields. J S Afr Inst Min Metall 115:563-568

Genc B, Onifade M, Cook A (2018) Spontaneous combustion risk on South African coalfields: Part 2. In: Proceedings of the 21st international coal congress of Turkey "ICCET" April 11-13, 2018, Zonguldak, Turkey, pp 13-25

Gouws MJ, Wade L (1989a) The self-heating liability of coal: predictions based on simple indices. Min Sci Technol 9:75-80

Gouws MJ, Wade L (1989b) The self-heating liability of coal: predictions based on composite indices. Min Sci Technol 9:81-85

Kaymakci E, Didari V (2002) Relations between coal properties and spontaneous combustion parameters. Turk J Eng Environ Sci

Kim CJ, Sohn CH (2012) A novel method to suppress spontaneous ignition of coal stockpiles in a coal storage yard. Fuel Process Technol 100:73-83

Mastalerz M, Drobniak A, Hower JC, O'keefe JMK (2010) Spontaneous combustion and coal petrology, In: Stracher GB, Sokol EE, Prakash A (eds) Coal and fires: a global perspective. CoalGeology and Combustion, vol 1, pp 47-62

Onifade M, Genc B (2018a) Establishing relationship between spontaneous combustion liability indices. In: Proceedings of the 21 st international coal congress of Turkey "ICCET" April 11-13, Zonguldak, Turkey, pp 1-11

Onifade M, Genc B (2018b) Prediction of the spontaneous combustion liability of coal and coal-shale using statistical analysis. Society of mining professors, 6th regional conference, March 12-13, Johannesburg, South Africa, pp 63-82 26(1):59-64 
Onifade M, Genc B (2018c) A review of spontaneous combustion studies-South African context. Int J Min Reclam Environ. https:// doi.org/10.1080/17480930.2018.1466402

Onifade M, Genc B (2018d) Spontaneous combustion of coals and coal-shales. Int J Min Sci Technol. https://doi.org/10.1016/j. ijmst.2018.05.013

Onifade M, Genc B (2018e) Modelling spontaneous combustion liability of carbonaceous materials. Int $\mathrm{J}$ Coal Sci Technol 5(2):191-212. https://doi.org/10.1007/s40789-018-0209-2

Onifade M, Genc B, Carpede A (2018) A new apparatus to establish the spontaneous combustion propensity of coals and coals. Int $\mathrm{J}$ Min Sci Technol. https://doi.org/10.1016/j.ijmst.2018.05.012

Panigrahi DC, Sahu HB (2004) Classification of coal seams with respect to their spontaneous heating susceptibility: a neural network approach. Geotech Geol Eng 22:457-476

Panigrahi DC, Saxena VK (2001) An investigation into spontaneous combustion characteristics of coals using differential thermal analysis. In: Proceedings of the 7th international mine ventilation congress, Krakow, Poland, 17-22 June 2001. EMAG, Cracow, pp 495-500

Phillips H, Chabedi K, Uludag S (2011) Best practice guidelines for South African Collieries, Coaltech report, pp 1-129
Restuccia F, Ptak N, Rein G (2017) Self-heating behaviour and ignition of shale rock. Combust Flame 176:213-219

Rumball JA, Thomber MR, Davidson LR (1986) Study of chemical reactions leading to spontaneous combustion of pyritic black shale at MT Whaleback, Western Australia. Western Australia, Symposia series, Australasian Institute of Mining and Metallurgy, pp 133-139

Smith MA, Glasser D (2005) Spontaneous combustion of carbonaceous stockpiles. Part II: factors affecting the rate of the lowtemperature oxidation reaction. Fuel 84(9):1161-1170

Uludag S, Phillips HR, Eroglu HN (2001) Assessing spontaneous combustion risk in South African coal mining by using a GIS tool. In: 17th International mining conference and exhibition, Turkey, pp 243-249

Wade L (1989) The propensity of South African coals to spontaneously combust. Ph.D. Thesis, Department of Mining Engineering, University of the Witwatersrand, Johannesburg, pp 162-166

Wade L, Gouws MJ, Phillips HR (1987) An apparatus to establish the spontaneous combustion propensity of South African coals. In: Proceedings of the symposium on safety in coal mines, CSIR, Pretoria, South Africa, pp 7.1-7.2 